\title{
Ultrasound guided TAP block for the treatment of postoperative prolonged pain - an alternative approach
}

\author{
Uzamıs postoperatif ăgrının tedavisinde ultrason yardımıyla \\ TAP blok - alternatif bir yaklaşım
}

Perihan EKMEKÇi,' Züleyha KAZAK BENGISUN,' Baturay Kansu KAZBEK,' Serdar HAN,'² Filiz TÜZÜNER'

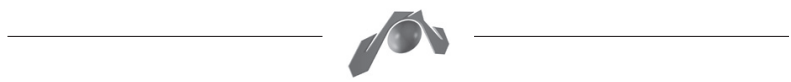

\begin{abstract}
Summary
Transversus abdominis plane (TAP) block is a relatively new regional anesthesia technique in which T7-12 intercostal nerves, ilioinguinal and iliohypogastric nerves, and cutaneous branches of L1-3 nerves are blocked between the internal oblique and transversus abdominis muscles. This technique is mostly used for the treatment of acute postoperative pain following abdominal surgery. In this case report, we evaluate the usage of TAP block in prolonged pain following upper abdominal surgery. Key words: Postoperative pain; prolonged pain; transversus abdominis plane block.
\end{abstract}

\section{Özet}

Transversus abdominis bloğu (TAB), L1-3 sinir köklerinin kutanöz dallarının, T7-12 interkostal snirlerin, ilioinguinal ve iliobipogastrik sinirlerin internal oblik ve transersus abdominis kasları arasinda bloke edildiği, görece olarak yeni bir rejyonel anestezi tekniğidir. Bu teknik daha çok abdominal cerrabi sonrası akut postoperatif ăgrının tedavisi için kullanılmaktadır. Bu olgu sunumunda üst abdominal cerrabi sonrası TAB'in kullanilmast anlatılmaktadır.

Anahtar sözcükler: Postoperatif ağrl; uzamış ağrl; ultrason; transversus abdominis blok.

\section{Introduction}

Transversus abdominis plane (TAP) block is a regional anesthesia technique where local anesthetic is injected to the neurovascular plane located between the internal oblique and transversus abdominis muscles. The nerves found in this neurovascular plane innervate the anterolateral abdominal wall and blockage of these nerves has been shown to be effective in providing analgesia after abdominal surgery. ${ }^{[1,2]}$
In this case report, we report an ultrasound guided TAP block which was performed for severe and prolonged postoperative pain which persisted for a month following diaphragma plication and umbilical hernia repair due to diaphragma eventration.

\section{Case Report}

Informed consent for publication of this case report was obtained from the patient. Diaphragma plica-

\footnotetext{
'Department of Anesthesiology and Reanimation, Ufuk University Faculty of Medicine, Ankara

${ }^{2}$ Department of Thoracic Surgery, Ufuk University Faculty of Medicine, Ankara

'Ufuk Üniversitesi Tıp Fakültesi, Anesteziyoloji ve Reanimasyon Anabilim Dalı, Ankara

${ }^{2}$ Ufuk Üniversitesi Tıp Fakültesi, Göğüs Cerrahisi Bilim Dalı, Ankara

Submitted (Başvuru tarihi) 21.04.2011 Accepted after revision (Düzeltme sonrası kabul tarihi) 25.10.2011

Correspondence (IIletişim): Dr. Perihan Ekmekçi. Konya Yolu, Mevlana Blv., №: 86/88, 06520 Balgat, Ankara, Turkey.

Tel: +90 - 312 - 2044098 e-mail (e-posta): erdogduperi@gmail.com
} 
tion and umbilical hernia repair was performed via left thoracotomy by thoracic surgery department on a 37-year-old male patient who had undergone an unsuccessful left subcostal laparotomy due to left diaphragma eventration 4 years ago. The patient was discharged on the third postoperative day with no respiratory problems and the diaphragma was normal in the chest X-ray. The patient was admitted a month later with complaints of severe pain on the previous laparotomy scar. The patient stated that the pain did not subside with oral analgesics during this period.

He was referred to the general surgery department concerning postoperative hernia and it was stated that the pain was not related to the postoperative hernia. When the patient was referred to our clinic on the postoperative thirty sixth day, his VAS score was $10 / 10$ and the pain interfered with mobilization, breathing, feeding and sleep. The pain was most intense on T7-10 dermatomes. There was no evidence of infection on the incision area. The pain did not subside with nonsteroidal anti-inflammatory drug (NSAID) and paracetamol treatment and tramadol PCA (10 mg/h infusion, $20 \mathrm{mg}$ bolus, 30 minutes lock out time) was used for 48 hours.

There was no improvement in VAS scores, feeding and sleep patterns deteriorated. In the postoperative thirty eighth day, ultrasound guided (Esaote ${ }^{\oplus}$, MyLab5, Italy) TAP block was performed. Following sterilization using $10 \%$ povidone iodine, a high-frequency $(18 \mathrm{MHz})$ lineer probe was placed transversely on the anterolateral abdominal wall between the left subcostal boundary and the iliac crest (Figure 1). The plane between the transversus abdominis and the internal oblique fascia was infiltrated using a $80 \mathrm{~mm} \mathrm{18G}$ Tuohy needle and $0.5 \% 20 \mathrm{ml}$ levobupivacaine was injected following negative aspiration test and the spread of local anesthetic was observed. 30 minutes after the intervention, the patient reported that the pain was gone and his VAS score was 1/10. 24 hours after the procedure he was still pain free and did not need NSAID or opioids, his feeding and sleep returned back to normal. The patient was prescribed pregabalin for the neuropathic component of the pain and discharged. On the follow up one month after the procedure, the patient was still pain free.

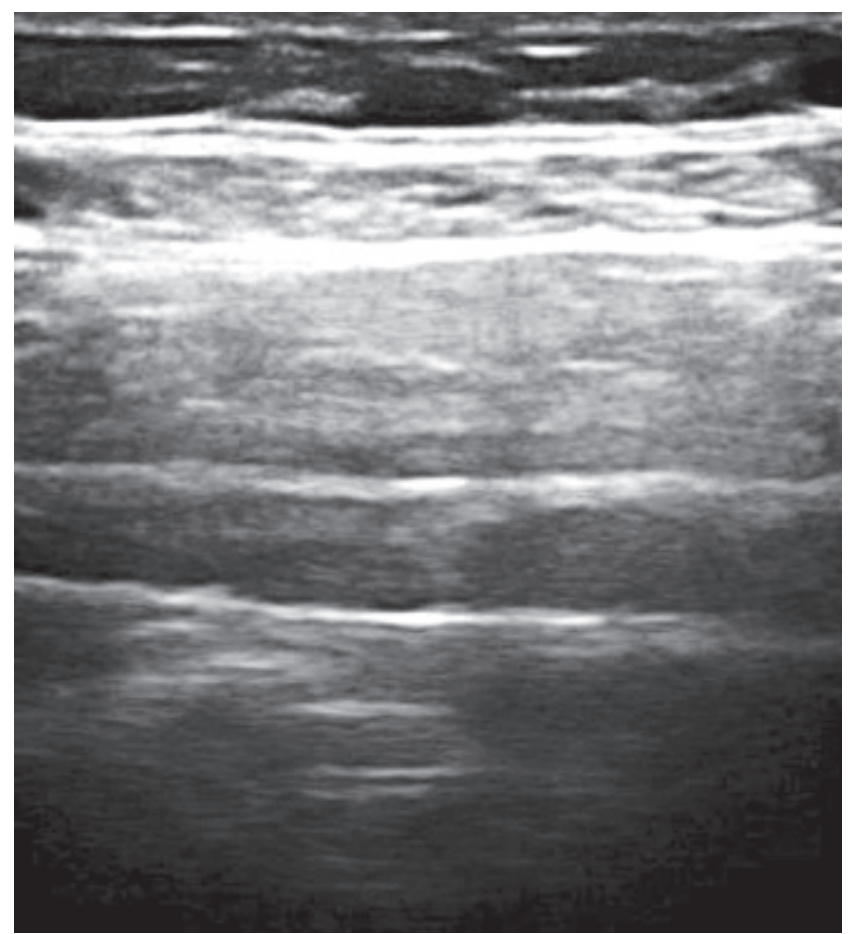

Fig. 1. Transversus abdominis plane block.

\section{Discussion}

Following surgery, many patients suffer from acute pain and most of the pain turns into chronic pain. Opioids are utilized for the treatment of this pain but they often fail to yield satisfactory results. In postoperative pain, neural damage is also present in addition to tissue damage and muscle spasm, thus it would be better to define this pain with neuropathic and inflammatory components rather than pure nociceptive.

TAP block is a relatively new technique and utilized more frequently in the the treatment of acute postoperative pain. There is not yet enough data on its use in prolonged pain. In this case report, TAP block is utilized in the treatment of postoperative prolonged pain. TAP block is a regional anesthesia technique where T7-12 intercostal nerves, ilioinguinal and iliohypogastric nerves, cutaneous branches of L1-3 nerves are blocked between the internal oblique and transversus abdominis muscles. ${ }^{[3]}$

TAP block, which was described by McDonell et al., has been successfully utilized in the treatment of post-caesarean section and laparotomy pain. ${ }^{[4]}$ Our patient had a postoperative umbilical hernia and a history of an unsuccessful diaphragma eventration 
repair which was performed 4 years ago. Following diaphragma plication and hernia repair which was performed by the thoracic surgery department using a left thoracotomy incision, the patient complained of severe pain and sensitivity on the previous laparotomy area. This was considered to be secondary to stretching of anterior abdominal muscles during diaphragma plication and the muscles were found to be atrophic in the CT scan. The patient had a pain which did not subside for thirty eight days despite the analgesics and effected his quality of life. Similarly, TAP block has been used to treat pain due to an abdominal wall hematoma which developed 48 hours following caesarean section. ${ }^{[5]}$

TAP block has been mostly used for the treatment of acute postoperative anterior abdominal wall pain following abdominal surgery. ${ }^{[1,6,7]}$ This case is unique for the use of TAP block for postoperative prolonged pain and points that TAP block is a promising alternative anlagesia technique not just for acute pain but also for prolonged postoperative pain.

\section{References}

1. McDonnell JG, O'Donnell B, Curley G, Heffernan A, Power C, Laffey JG. The analgesic efficacy of transversus abdominis plane block after abdominal surgery: a prospective randomized controlled trial. Anesth Analg 2007;104(1):193-7.

2. Farooq M, Carey M. A case of liver trauma with a blunt regional anesthesia needle while performing transversus abdominis plane block. Reg Anesth Pain Med 2008;33(3):274-5.

3. El-Dawlatly AA, Turkistani A, Kettner SC, Machata AM, Delvi $M B$, Thallaj $A$, et al. Ultrasound-guided transversus abdominis plane block: description of a new technique and comparison with conventional systemic analgesia during laparoscopic cholecystectomy. Br J Anaesth 2009;102(6):763-7.

4. Niraj G, Searle A, Mathews M, Misra V, Baban M, Kiani S, et al. Analgesic efficacy of ultrasound-guided transversus abdominis plane block in patients undergoing open appendicectomy. Br J Anaesth 2009;103(4):601-5.

5. Randall IM, Costello J, Carvalho JC. Transversus abdominis plane block in a patient with debilitating pain from an abdominal wall hematoma following cesarean delivery. Anesth Analg 2008;106(6):1928.

6. O'Donnell BD, McDonnell JG, McShane AJ. The transversus abdominis plane (TAP) block in open retropubic prostatectomy. Reg Anesth Pain Med 2006;31(1):91.

7. McDonnell JG, Curley G, Carney J, Benton A, Costello J, Maharaj $\mathrm{CH}$, et al. The analgesic efficacy of transversus abdominis plane block after cesarean delivery: a randomized controlled trial. Anesth Analg 2008;106(1):186-91. 